\title{
MÁLFREGNIR
}

\author{
Jóhannes B. Sigtryggsson
}

\section{Íslensk stafsetningarorðabók}

\section{Inngangur}

Í október 2020 var hleypt af stokkunum nýrri vefsíðu Íslenskrar stafsetningarorðabókar (hér eftir ÍS) (https://stafsetning.arnastofnun.is/) sem er opinber réttritunarorðabók fyrir íslensku. Petta er í fyrsta sinn sem pessi orðabók er birt á eigin vefsíðu en hún á sér hins vegar lengri sögu.

\section{Bakgrunnur}

\subsection{Saga orðabókarinnar}

Íslensk stafsetningarorðabók var í fyrsta sinn gefin út 2006 og hét pá Stafsetningarorðabókin. Íslensk málstöð, sem var skrifstofa Islenskrar málnefndar, sá pá um útgáfuna. Fjallað er um aðdraganda verksins í inngangi 1. útgáfu hennar (Stafsetningarorðabókin 2006:7-12). ${ }^{1}$ Pessi orðabók átti rætur að rekja til minni stafsetningarorðabókar,

1 Inngangurinn er endurbirtur á vefsíðu Íslenskrar stafsetningarorðabókar (https:// stafsetning.arnastofnun.is/um/formali-2006/).

Orð og tunga 23 (2021), 153-160, https://doi.org/10.33112/ordogtunga.23.8

(C) höfundur CC BY-NC-SA 4.O. 
Réttritunarorðabókar handa grunnskólum (1989) sem málnefndin gaf út ásamt Námsgagnastofnun.

Við sameiningu stofnana á sviði íslenskra fræða, par á meðal Íslenskrar málstöðvar, í Stofnun Árna Magnússonar í íslenskum fræðum árið 2006 afhenti Íslensk málnefnd stofnuninni Stafsetningarorðabókina. Árnastofnun varð pá um leið skrifstofa málnefndarinnar.

Vinna við endurskoðun 1. útgáfu hófst 2011 og hefur staðið yfir síðan með hléum. Önnur útgáfa hennar var eingöngu gefin út á vef árið 2016 í ritstjórn Jóhannesar B. Sigtryggssonar (um nýjungar í pessari útgáfu sjá 3. kafla hér fyrir aftan). ${ }^{2}$

\subsection{Opinber réttritunarorðabók}

Hvað merkir að Íslensk stafsetningarorðabók sé opinber réttritunarorðabók? Í upprunalegum lögum um Íslenska málnefnd frá 1990 (nr. 2/1990) stendur í 2. grein, 5. lið: „Íslensk málnefnd gefur út rit til fræðslu og leiðbeiningar um íslenskt mál, p. á m. stafsetningarorðabók og önnur hagnýt orðasöfn." Parna er pví kveðið á um að málnefndin eigi meðal annars að gefa út stafsetningarorðabók. Í samræmi við petta stendur aftan á kápu Stafsetningarorðabókarinnar (2006): „Stafsetningarorðabókin er hin opinbera réttritunarorðabók, samin í umboði Íslenskrar málnefndar skv. lögum nr. 2/1990.“ Petta er enn í gildi og rímar einnig við hlutverk Stofnunar Árna Magnússonar í íslenskum fræðum (sjá 3. gr. c í lögum nr. 40/2006 um stöðu íslenskrar tungu og íslensks táknmáls) par sem segir að hún eigi meðal annars að: „stuðla að aukinni pekkingu á íslenskri tungu, eflingu hennar og varðveislu í ræðu og riti og veita ráðgjöf og leiðbeiningar um málfarsleg efni á fræðilegum grundvelli, par á meðal um íðorð og nýyrði“.

\subsection{Endurskoðun ritreglna og Íslensk stafsetningarorðabók}

Samkvæmt lögum um stöðu íslenskrar tungu og íslensks táknmáls (nr. 61/2011) er eitt af verkefnum Íslenskrar málnefndar að semja ritreglur. Í 6. gr. laganna stendur: „Íslensk málnefnd semur íslenskar ritreglur sem gilda m.a. um stafsetningarkennslu í skólum og ráðherra gefur út. Grundvallarbreytingar á ritreglum eru háðar sampykki ráðherra."

2 Nánar um vinnuna við 2. útgáfu má lesa hér: https://stafsetning.arnastofnun.is/ um/2-utg-2016/. 
Vinnuhópur Íslenskrar málnefndar um ritreglur vann með hléum við endurskoðun peirra frá 2010 til 2015 og skilaði pá skýrslu til málnefndarinnar sem varð grunnur að nýjum stafsetningarreglum sem mennta- og menningarmálaráðherra auglýsti 2016 (nr. 695/2016). Nýjar greinarmerkjareglur voru síðan auglýstar 2018 (nr. 800/2018). ${ }^{3}$

Endurskoðun ritreglnanna var ætíð hugsuð í samhengi við vinnu við nýja útgáfu Stafsetningarorðabókarinnar og var hún að vissu leyti hvati hennar. Núverandi hlutverk Íslenskrar stafsetningarorðabókar er pví að vera helsta birtingarmynd gildandi ritreglna frá 2016 og 2018 og að sýna hvernig túlka á reglurnar við ritun miklu fleiri orða en hægt er að tilgreina í reglunum sjálfum. Orðabókin sinnir pví mikilvægu hlutverki í að breiða út pessar opinberu ritreglur.

\subsection{Fyrri birting og eigin vefsíða}

Undirbúningur undir endurskoðun Stafsetningarorðabókarinnar fólst meðal annars í að láta hanna nýjan gagnagrunn fyrir hana. Steinpór Steingrímsson, verkefnisstjóri í upplýsingatækni á Stofnun Árna Magnússonar í íslenskum fræðum, hannaði hann í samstarfi við ritstjóra árin 2013-2014. Gagnagrunnurinn gerði mögulega birtingu orðabókarinnar á vefgátt Árnastofnunar, málið.is, og par hefur hún verið aðgengileg frá 2016 og er enn pótt hún sé nú einnig komin á nýja vefsíðu. Fyrsta útgáfa orðabókarinnar (2006) hefur einnig lengi verið aðgengileg á snara.is.

Pótt Íslensk stafsetningarorðabók hafi um skeið verið aðgengileg á málið.is var pó einnig áhugi á pví að birta hana á eigin vefsíðu. Vinna við gerð slíkrar síðu hófst um mitt ár 2020. Trausti Dagsson, verkefnisstjóri í upplýsingatækni á Stofnun Árna Magnússonar í íslenskum fræðum, skipulagði notendaviðmót og hannaði vefsíðuna ásamt ritstjóra og bjó hana til. Hún er byggð á fyrrnefndum gagnagrunni Steinpórs Steingrímssonar.

Í tilefni af opnun pessarar nýju síðu var orðabókinni gefið nýtt heiti (Íslensk stafsetningarorðabók) sem pó vísar til pess fyrra.

\section{Nýjungar í 2. útgáfu (2016)}

Megintakmarkið með 2. útgáfu Stafsetningarorðabókarinnar (2016) var

3 Um nýjungar í ritreglunum sjá til að mynda Jóhannes B. Sigtryggsson $(2016,2018$, 2019a, 2019b). 
að bæta við vísunum í ritreglur Íslenskrar málnefndar, millivísunum og endurskoða orðabókina til samræmis við nýjungar í ritreglum.

Helsta nýjungin í nýju útgáfunni var umfangsmikið kerfi vísana í ritreglur par sem hægt var að sjá viðeigandi stað í reglunum sjálfum með pví að smella á númer ritreglu. ${ }^{4}$ Samtals var bætt við um 2900 vísunum í ritreglur. Orðaforðinn var par með tengdur miklu nánar en áður við opinberar ritreglur. ${ }^{5}$ Mynd 1 sýnir uppflettiorðið alaskabjörn ásamt tilvísun í ritreglur.

alaskabjörn kk.

-inn, -bjarnar; -birnir (dýrafræði)

Sjá §1.3.3.2 a i Ritreglum

Mynd 1: Uppflettiorð með tilvísun í ritreglur.

Í 1. útgáfu Stafsetningarorðabókarinnar (2006) voru nær engar millivísanir og pá eingöngu úr aukamyndum fornafna í aðalmyndir (t.d. sitt $\rightarrow$ sinn) eða í flettur par sem var að finna töflur með beygingarlýsingum fornafna (t.d. önnur $\rightarrow$ annar).

Í 2. útgáfu 2016 var bætt við fjölmörgum vísunum á milli jafngildra mynda (einnig) og par sem vísað var úr síðri mynd í betri (táknað með sjá og síðar með $\rightarrow$ ). Á Mynd 2 má sjá uppflettiorðið skrýtinn með vísun í jafngilda mynd.

\section{skrýtinn lo.}

skrýtin; skrýtið, STIGB -nari, -nastur (einnig ritað skrítinn)

Mynd 2: Uppflettiorðið skrýtinn með vísun í jafngilda mynd.

Á Mynd 3 er sýnd vísun úr síðri mynd í betri.

$$
\text { tágrannur } \longrightarrow \text { tággrannur }
$$

Mynd 3: Vísun úr síðri mynd í betri er táknuð með ör.

4 Á https://ritreglur.arnastofnun.is/.

5 Í1.útgáfu Stafsetningarorðabókarinnar hafði verið vísað úr nokkrum flettum í greinar í ritreglum Íslenskrar málstöðvar sem birtar höfðu verið í orðabókinni (2006:673734). Sjá t.d. alls konar $§ 76$. Pessar vísanir voru hins vegar ekki umfangsmiklar. 


\section{Nýjungar í birtingu}

Á nýju vefsíðunni (https://stafsetning.arnastofnun.is/) eru nokkrar nýjungar í birtingu efnis. Tenging við ritreglur er nú enn nánari. Ef smellt er á númer ritreglu við flettu opnast réttur staður í peim á vefsíðu ÍS og ekki parf að fara af henni til að skoða regluna. Á Mynd 4 er sýnt hvað birtist pegar smellt er á númer ritreglu við orðið pekingönd. Í pessu tilviki er pað grein númer 1.3.3.2 c sem fjallar um hvernig rita á heiti matvæla.

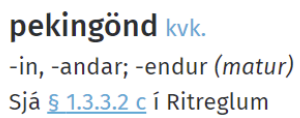

Mynd 4: Uppflettiorðið pekingönd með upplýsingum úr ritreglum.

Í vinnu við Stafsetningarorðabókina (2006) höfðu upplýsingar um efnissvið víða verið skráðar. Pessar upplýsingar voru hins vegar hvorki sýndar í prentuðu orðabókinni né í 2. útgáfu (2016) á málið.is. Á nýrri vefsíðu orðabókarinnar eru pessar upplýsingar um efnissvið í fyrsta sinn birtar og eru pær hafðar inni í svigum. Yfirferð og samræming pessara upplýsinga er hins vegar ekki lokið og ber að líta á pær með peim fyrirvara. Á Mynd 5 sést efnissvið uppflettiorðsins barokk innan sviga.

\section{barokk hk.}

-ið, barokks barokk·still; barokk·tími; barokk·tónlist (listir)

Mynd 5: Uppflettiorðið barokk með upplýsingum um efnissvið. 
Önnur nýjung er að settar hafa verið inn merkingarupplýsingar við um 400 orð í ÍS, eins og sést á Mynd 6. Petta eru knappar upplýsingar innan einfaldra gæsalappa sem eiga að nægja til að greina á milli líkra orða (t.d. eiði og eyði).

eið̇i hk. 'grandi'

-ð, eiðis; eiði

Sjá § 6.5 î Ritreglum

Mynd 6: Uppflettiorðið eiði með merkingarupplýsingum.

Auk pess hafa verið settar inn upplýsingar við um 1400 orð um skyldleika peirra við önnur. Petta er sérstaklega gert til að skýra uppruna og stafsetningu vandritaðra orða, eins og sjá má á Mynd 7.

kýla so.

kýldi, kýlt (skylt kúla)

Mynd 7: Uppflettiorðið kýla með upplýsingum um skyldleika við orðið kúla.

Oft er sýnd orðskipting á aðalsamskeytum í samsettum orðum í dæmum eins og á Mynd 8. Skil á milli samskeyta eru sýnd með miðstæðum punkti (·). Pessar upplýsingar voru skráðar í vinnu við 1. útgáfu bókarinnar (2006) en voru ekki sýndar par. Pað var ekki fyrr en með birtingu orðabókarinnar á málið.is sem pað var gert.

\section{tilkynning kvk.}

-in, -kynningar; -kynningar tilkynninga(r)·skylda

Mynd 8: Orðskipting sýnd með miðstæðum punkti á aðalsamskeytum samsetts orðs í dæmum.

Nú er einnig unnið að pví að setja inn upplýsingar um orðskiptingu við allar flettur eða uppflettimyndir í ÍS. Skiptingin verður sýnd með lóðstriki ( I ) eins og á Mynd 9.

emb ætti hk.

-ð, embættis; embætti embættis·aðall

Mynd 9: Uppflettiorðið embætti með lóðstriki sem sýnir orðskiptingu. 


\section{Niðurlag}

Ný vefsíða Íslenskrar stafsetningarorðabókar býður upp á mikla möguleika á að próa birtingu gagna í henni. Með sífellt nánari tengingu við ritreglur Îslenskrar málnefndar styrkja orðabókin og reglurnar hvort annað.

\section{Heimildir}

Auglýsing um setningu íslenskra ritreglna nr. 655/2016. 10. ágúst 2016. Stjórnartíðindi. B-deild. www.stjornartidindi.is (sótt 15.1.2021).

Auglýsing um setningu íslenskra ritreglna nr. 800/2018. 31. ágúst 2018. Stjórnartídindi. B-deild. www.stjornartidindi.is (sótt 15.1.2021).

Íslensk stafsetningarorðabók. Ritstjóri: Jóhannes B. Sigtryggsson. Stofnun Árna Magnússonar í íslenskum fræðum. https://stafsetning.arnastofnun.is/

Jóhannes B. Sigtryggsson. 2016. Greinargerð um helstu breytingar á ritreglum. Skíma 39:40-41.

Jóhannes B. Sigtryggsson. 2018. Nye islandske retskrivningsregler og den islandske retskrivningsordbog. İ: Ásta Svavarsdóttir, Halldóra Jónsdóttir, Helga Hilmisdóttir, Pórdís Úlfarsdóttir (ritsti.). Nordiske Studier i Leksikografi. Rapport fra 14. Konference om Leksikografi i Norden Reykjavík 30. maj-2. juni 2017, bls. 230-236. Reykjavík.

Jóhannes B. Sigtryggsson. 2019a. Nýjar ritreglur Íslenskrar málnefndar um greinarmerkjasetningu. Yfirlit yfir breytingar. Orð og tunga 21:169-174.

Jóhannes B. Sigtryggsson. 2019b. Hvað eru ritreglur Íslenskrar málnefndar. Málræktarpistill 20.9.2019. https://www.arnastofnun.is/is/utgafa-og-gagnasofn/pistlar/hvad-eru-ritreglur-islenskrar-malnefndar (sótt 15.1.2021).

Lög um Íslenska málnefnd nr. 2/1990. https://www.althingi.is/lagas/132a/ 1990002.html (sótt 15.1.2021).

Lög um stöðu íslenskrar tungu og íslensks táknmáls nr. 61/2011. https://www. althingi.is/altext/stjt/2011.061.html (sótt 15.1.2021).

Réttritunarorðabók handa grunnskólum. 1989. Ritstjóri: Baldur Jónsson. Reykjavík: Námsgagnastofnun og Îslensk málnefnd.

Stafsetningarorðabókin. 2006. Ritstjóri: Dóra Hafsteinsdóttir. Reykjavík: Íslensk málnefnd. 


\title{
Lykilorð
}

stafsetning, réttritun, stafsetningarorðabækur, opinber stafsetning

\section{Keywords}

spelling, orthography, orthographical dictionaries, official spelling

\author{
Abstract \\ Jóhannes B. Sigtryggsson \\ Stofnun Árna Magnússonar i íslenskum fræðum \\ Laugavegi 13 \\ IS-101 Reykjavík \\ johannes.b.sigtryggsson@arnastofnun.is
}

The official Icelandic spelling dictionary, Íslensk stafsetningarorðabók (1st edition 2006), was made available digitally for the first time in 2020. In the article, I discuss changes in the presentation of the dictionary that the online format makes possible. 